\title{
Interfaces
}

\section{The Legacy of American Photojournalism in Ken Burns's Vietnam War Documentary Series}

\section{Camille Rouquet}

\section{(2) OpenEdition \\ 1 Journals}

\section{Electronic version}

URL: http://journals.openedition.org/interfaces/647

DOI: $10.4000 /$ interfaces.647

ISSN: 2647-6754

\section{Publisher:}

Université de Bourgogne, Université de Paris, College of the Holy Cross

\section{Printed version}

Date of publication: 21 June 2019

Number of pages: $65-83$

ISSN: 1164-6225

\section{Electronic reference}

Camille Rouquet, "The Legacy of American Photojournalism in Ken Burns's Vietnam War Documentary Series", Interfaces [Online], 41 | 2019, Online since 21 June 2019, connection on 07 January 2021. URL: http://journals.openedition.org/interfaces/647 ; DOI: https://doi.org/10.4000/interfaces.647

Les contenus de la revue Interfaces sont mis à disposition selon les termes de la Licence Creative Commons Attribution 4.0 International. 


\title{
THE LEGACY OF AMERICAN PHOTOJOURNALISM IN KEN BURNS'S VIETNAM WAR DOCUMENTARY SERIES
}

\author{
Camille Rouquet \\ LARCA/Paris Sciences et Lettres
}

In his review of The Vietnam War, the 18-hour-long documentary series directed by Ken Burns and Lynn Novick released in September 2017, New York Times television critic James Poniewozik wrote:

"The Vietnam War" is not Mr. Burns's most innovative film. Since the war was waged in the TV era, the filmmakers rely less exclusively on the trademark "Ken Burns effect" pans over still images. Since Vietnam was the "living-room war," played out on the nightly news, this documentary doesn't show us the fighting with new eyes, the way "The War" did with its unearthed archival World War II footage. ${ }^{1}$

Ken Burns's series might not be his most innovative work, but it certainly accomplishes a number of impressive feats and offers a fresh look at the memorialization of this war, notably through an original dramatization of iconic press photographs.

As early as 1984, some Vietnam decision-makers expressed regrets at prolonging the war in a panel of experts assembled by the Defense Information School (Vietnam 10 Years Later). By 2017, it had become effectively unthinkable for anyone to suggest that the war in Vietnam achieved any positive results, regardless of personal ideologies. Burns and Novick seem to be aware of the stakes involved in making a documentary about a war that started over fifty years ago and whose social memory has become infused with oral and visual evidence of the sufferings endured by many. This documentary is a commercial endeavor that has to engage with as wide an audience as possible; calling on familiar and iconic pictures is useful to that purpose. But the filmmakers also demonstrate a desire to introduce some novelty and educational moments into their narrative. They move on from decades of disheartened analyses of what went wrong in Vietnam and choose to give a voice to people from all sides of the conflict, from American veterans to Viet Cong officers, in a desire for inclusivity

The War is one of Ken Burns and Lynn Novick's previous documentary mini-series. It premiered in 2007 and told a story of World War II that did not rely on historians' analyses but on the testimonies of regular American people - veterans or civilians — who experienced the war. 
and comprehensiveness. These additions are also essential to the tale of reconciliation aimed at by Burns's team:

There is no simple or single truth to be extracted from the Vietnam War. Many questions remain unanswerable. But if, with open minds and open hearts, we can consider this complex event from many perspectives and recognize more than one truth, perhaps we can stop fighting over how the war should be remembered and focus instead on what it can teach us about courage, patriotism, resilience, forgiveness and, ultimately, reconciliation. (Burns and Novick)

The filmmakers provide content suitable for all viewers - those who want to learn all about the war and those who want to supplement existing knowledge. The goal is visibly to offer an educational documentary; in order to do that, they take care to review even the most famous historical features of the war - such as the antiwar movement, the media's involvement, and iconic photographs-, to analyze old and newly-discovered primary sources and to derive intelligent conclusions from them. In that regard, the documentary contributes to the visual historiography of the Vietnam War, but also to its memorialization because it propels the war more deeply into the social and cultural memory of the United States and of Vietnam in the shape of a new media production.

The dramatization of the iconic photographs from Vietnam strongly contributes to this new memorialization. Icons are among the most universally recognized elements from the war, even though they do not much depict the military side of the conflict like iconic photographs from previous wars. But even in a documentary series that highly focuses on the military side of the story, they could not be left aside because they are deeply anchored into the history of the Vietnam War. It is undeniable, however, that Burns and Novick take a new approach in this documentary, as they reconcile two facets of iconic photographs that have become progressively separated since the end of the war: the historical and the symbolic. This has an effect on the memorialization of the pictures because they are rarely contextualized for the general public nowadays, and because this documentary is a new illustration of the icons' power to embody the theory of media influence.

\section{Media Involvement During the War}

Historians discussed the objectivity and influence of the media for decades once it had become clear that the media were widely credited with — or blamed for - turning public opinion against the war through negative coverage. Iconic photographs — sometimes simply called "icons" - are famous images that 
most people are familiar with even though they cannot always identify their context of origin. In the case of the Vietnam War, there are four icons: the self-immolation of Buddhist monk Thich Quang Duc (Malcolm Browne, 1963), the Saigon execution during the Tet Offensive (Eddie Adams, 1968), the Kent State shooting (John Paul Filo, 1970), and the girl burned by napalm (Nick Ut, 1972). ${ }^{2}$ Icons occupy a significant space in the history of the Vietnam War as they have become the embodiment of the power of the media.

It is widely accepted that the all-but-total freedom of the media during the war had a strong impact on the public. The nature of this impact is, however, subject to discussion. Ignoring a number of socio-economic factors, early historians looked at media images and at the drops in public support for the war that chronologically followed them, and retrospectively concluded that the media had turned public opinion: "It is widely held that the media 'lost the war' by exposing the general population to its horrors and by unfair, incompetent and biased coverage" (Herman and Chomsky 169). With the emergence of iconic images in the late 1980s (Rouquet, "Shaping the Notion"), this belief was transferred onto a set of photographs which are now widely believed to be autonomously influential, as exemplified by statements like these: "[The picture of the Saigon execution] roused national anger in the United States against the summary street justice administered by a Vietnamese general" (Marien 367) and "This 1972 photograph - more than any other single image-made America conscious of the full horror of the Vietnam War" (Goldberg 244).

Since the 1990s, many studies of media coverage and of the evolution of public opinion have shown that the media merely reflected public opinion instead of influencing it (Hallin), and that making an argument of radical influence is greatly reductive (Domke 132). The Vietnam War was a fundamental period in the evolution of the media: it greatly increased the freedom of the press, introduced more accurate depictions of modern warfare and made way for more graphic images in mainstream papers. It also made political and military administrations accountable for their mistakes - a lesson strongly reflected in the Vietnam Syndrome and subsequent press censoring during the Gulf War. These factors, combined with the remarkable aura of iconic images, have had a significant impact on the memorialization of the war and cast off an array of factors that should be considered to explain why the war was lost and why a majority of the American public stopped supporting it in the late 1960s (Rouquet, "Shaping the Notion"). It now seems that contemporary works on the history of the Vietnam War can no longer forgo mentioning the famous images seen on television and in the press because these have

This categorization is not arbitrary but ensues from a study of the historiography of Vietnam War media coverage which recognizes a number of moderately famous photographs and four true icons - singled out because of their alleged universal fame and their inclusion in popular culture (Rouquet, Les icônes du Vietnam). 
been imbued with powers of persuasion. They are now part of the "100 Most Influential Images of All Time" selected by Time magazine and are fully implanted in popular culture (as exemplified by this Banksy print of Kim Phuc flanked by Ronald McDonald and Mickey Mouse).

\section{A New Historiographical Stage}

Burns and Novick's series stands as the next logical stage in the historiography of the war and shows signs of awareness of recent works that reconsider the influence theory and absolute powers of iconic photographs. Although this documentary series is highly focused on warfare and veteran testimonies, the media do find reasonable space but are never credited with radical influence.

The series by Burns and Novick is made up of ten episodes spanning chronologically from 1858 to 1982 . The first episode, dealing with the $1858-1961$ period, is a condensed summary of the French colonization of Indochina and the various reasons that led to American presence in the State of Vietnam. The final episode recounts the fall of Saigon in great detail and includes the plans for the Washington Vietnam War Memorial opened in November 1982 as it fits the filmmakers' message of hope and healing. With 18 hours of air time, this documentary series is a new platform that offers its viewers an amount of details previously reserved to history books. The filmmakers also seize the opportunity to include new information about the successive governments that waged war in Vietnam in the form of tapes declassified in 2013. These tell stories of treasonous behavior by Richard Nixon, ${ }^{3}$ harsh declarations by Lyndon B. Johnson regarding the media and the antiwar movement, ${ }^{4}$ and so on. The antagonistic relationships between the media and any 1960s administrations are at the root of the theory of media influence which was later refuted (Rouquet, Les icônes du Vietnam). The mere illustrative value given to these quoted moments in the series shows that the filmmakers are up-to-date with the historiography. Burns and Novick refrain from instrumentalizing the old antagonism and from making any sensational use of the tapes. The goal here is clearly to contribute to the historiography an updated retelling of the war that leaves it primary sources open to interpretation.

Episode 7, 51:34. Richard Nixon secretly maneuvered the South Vietnamese government in order to influence his own election in 1968. President Lyndon B. Johnson learned about it through CIA and FBI wiretaps but could not publicize the information.

4. $\quad$ Episode 3, 1:19:11. Johnson called the head of CBS to admonish him for broadcasting Morley Safer's report on Marines burning huts at Cam Ne.

Episode 5, 52:40. After the 1967 March on the Pentagon, Johnson was recorded telling former president Dwight Eisenhower that he considered antiwar protestors to have mental problems. 
Delving into the behavior of journalists and media outlets has been the focus of scholars in the fields of media and communications studies, and to some extent of historians of photography. Specifically, debates over the influence of iconic images in the 1990s gave them exponential space in the memorialization of the war. In this series, however, the media are handled the same as they were in the academic field of history. This field had traditionally observed the political and military decision-making and actual warfare to explain the defeat against the North Vietnamese regime. Media coverage is generally mentioned as a side effect of waging war in a modern society; Burns and Novick's documentary works on a similar principle but does so with a fresh twist. As a visual history of the war, it cannot function without images - either from the press or television; but what defines this documentary series is the types of images it does include and how it contextualizes them. In that regard, Burns and Novick adopt a middle-of-the-road approach that reconciles elements from all the historiographical fields mentioned above.

Calling on the familiar, the filmmakers include interviews with Neil Sheehan (New York Times) and Joseph Galloway (United Press International) who are both alive and able to comment retrospectively on the difficulties of their job. These interview segments almost feel educational without bordering on popularization. They provide the most dilettante viewers with a precise understanding of their profession without requiring them to read one of the many memoirs written by reporters after the war. For the viewers well-versed in history, snapshots and stories of David Halberstam, Malcolm Browne, Philip Caputo and Horst Faas make for engaging storytelling all through the ten episodes. Additional depth is given to the documentary when it features photographs by other photographers never mentioned in the series but whose work will be recognized by specialists or amateur historians: Larry Burrows and Don McCullin among others. ${ }^{5}$

Because the Vietnam War was nicknamed the "Television War," more space is given to television journalists, and familiar anchor Walter Cronkite is shown several times broadcasting from CBS studios or from Vietnam. His "Report from Vietnam" (episode 6, 1:04:30) holds a special place in the social memory of the war. When he came back from covering the Tet Offensive and expressed his disillusionment on CBS Evening News, President Johnson famously said: “If I've lost Cronkite, I've lost Middle America." Public support for the war increased in the month that followed the attacks on Saigon, but dropped in March 1968. Next to iconic photographs, Cronkite's report, which was viewed by millions of Americans, is the piece of media content that had been credited with the strongest influ-

Episode 3, 1:07:00. Photographs from Burrows's “One Ride With Yankee Papa 13" portfolio are shown on the screen. Episode 10, 1:16:00. McCullin's "Shell Shock" portrait is shown during a segment on veterans diagnosed with posttraumatic stress disorder. 
ence on public opinion and more specifically on Johnson's decision not to run for reelection in 1968 (Achenbach). This requires a mention in a documentary on the war, but here again Burns and Novick favor a neutral approach and resist interpretation. Cronkite himself has declared that his report did not have "a principal effect" on any decisions and that many other implications have to be considered. ${ }^{6}$ The filmmakers seem to take into account the most recent findings that debunked the influence theory and offer a chronological and factual account of the events. They convey the significance of Cronkite's report in reference to his popularity and audience - he is referred to as "the respected anchor"-but refrain from suggesting that his change of heart might have infected others.

This non-committal approach is the standard norm in the entire series. The narration is mostly chronological and takes care not to use vocabulary suggestive of influence. Editing choices reflect the significance of the news media during the war; viewers are regularly reminded of their contributions to public information, notably through shots of newspaper spreads or camera crews. This method is also strengthened by a powerful visual device: viewers are repeatedly given to see archival footage of battles, political events or of the lives of Vietnamese civilians inserted into the frame of a television monitor. This aims at reproducing the experience of 1960s Americans who viewed events as they were reported on television. The effect is convincing; there is no forgetting that the media were responsible for the public's detailed knowledge and precise understanding of how the war was fought. Choosing not to editorialize over these shots preserves the topic of media reporting from suggestions of nefarious interference. The only drawback to this visual device is that it could mislead viewers into thinking that all the footage displayed that way was shown on television, although the series gives no evidence to support this.

\section{Press Photographs in A Documentary: What, When and How?}

Burns and Novick's series gives television enough space to recognize it as a major contributor to public information, but overall press photography is presented as the most memorable medium, no doubt a consequence of the exceptional aura of some photographs in social and cultural memory. This preference is visible from the start and from the way the series was publicized. A video made for promotional purposes is featured on the PBS Vietnam War website as a teaser for the series. The video aims at summarizing the unanimous praise by American "top critics" and therefore at attracting viewers. As any teaser, it is very short and is made of bursts of videos showing very diverse scenes 
designed to reflect the comprehensiveness of the proposed retelling; it also includes three black and white photographs. One of those is used as the video's thumbnail and should catch a few eyes. Burst of Joy is not an iconic photograph but it won the Pulitzer Prize for Feature Photography in 1974. It is one of the most memorable images from the war and shows an American girl running towards her father, a POW released by the North Vietnamese when U.S. troops withdrew in $1973 .^{7}$

One of the few images of hope to have made it to the top of the Vietnam visual archive, this photograph is a pertinent choice for a teaser because it is a perfect echo of the filmmakers' intentions: to work toward reconciliation. Arguably trying not to reveal too much - this is merely a teaser after all - the editors choose to include only one of the four icons of Vietnam: the Kent State shooting photograph. This choice is significant, because, next to Burst of Joy, it invites the American audience to reflect on their own history and identity. Most of the other memorable photographs from Vietnam depict Vietnamese people, an ethnic factor that could possibly countervail the filmmakers' need for relatability in this specific clip.

Throughout the series, we see many generic photographs typically used as illustrations or evidence of the stories told by the narrator. These visual anchors are regularly timed to add meaning to oral testimonies; the most familiar photographs among those tend to be used in original ways. In episode 3, the Time magazine photo essay "One Ride With Yankee Papa 13" by Larry Burrows illustrates a segment on the growing presence of American journalists in Vietnam following Johnson's decision to send ground troops over in March 1965. Historically this photo essay illustrated the hardship of American troops because it eloquently depicted the dangers of fighting in the jungle and featured wounded Marines. The famous Reaching Out photograph also receives unexpected treatment: it appears on the screen during the interview of Le Cong Huan, a former officer of the National Liberation Front (Viet Cong). Huan is one of several former enemies whose testimony is heard in the series, in Burns and Novick's effort to balance perspectives. In this segment, the goal is to erode antagonism and resentment; Huan is testifying to the great humanity and courage he saw in the American fighters he encountered in Vietnam. This is built as a reconciliatory moment; the segment appropriates a picture heretofore restricted to bleak tales of suffering and death and gives it a new backdrop of hope and positivity. These interpretative variations suggest that the filmmakers have decided to expand on the meaning of these photographs and to attempt to give them new depth. This, they share with viewers able to identify the photographs and remember their original meaning. For those who cannot, the familiar iconic photographs receive a specific treatment and act as representatives of press photography. 


\section{What Does the Series Do with Icons?}

Viewers find references to the four iconic photographs as early as the introduction sequence, in the first episode. In this sequence, various clips are shown backward. We see helicopters emerging from the ocean to land back on the battleships off which they were pushed; we see napalm fire disappearing back into the jungle, bullets speeding into guns barrels, protesters walking backwards, and so on. The filmmakers dramatize their desire to understand "what happened" through an artificial rewinding of history.

The introduction sequence has to convince potential viewers to stick around and watch the full documentary. It is therefore essential to select as visual anchors images that are both familiar and intriguing. In that regard, Burns and Novick make a persuasive choice: iconic photographs are first referred to in movie form in order to build suspense. To the exception of the Kent State Shooting icon, all the iconic events from Vietnam were captured both on photo and movie camera. At this point in their afterlife, iconic photographs have become so familiar that they can be easily recognized in different formats and across a range of different media reappropriations. Some have been made into statues, some are sketched on public walls or included in artworks; their recognizability is what makes them iconic. To capture the attention of viewers, Burns and Novick arguably choose to show the videos of the Saigon Execution and of the Napalm Girl because they are instantly identified by a majority of viewers and start an engaging cognitive process as viewers picture the associated photographs in their minds.

The other two iconic moments might be harder to identify in this sequence, as they are based on the principle of referentiality. The immolation of Thich Quang Duc in 1963 was filmed by a camera crew and is easy to find on the internet in its color version. But as it was filmed by a shaky and distant camera, it would be hard to use in a fast sequence like this one. Instead, the scene from another immolation by fire is used and seems to be sufficient to call to mind the image of Thich Quang Duc burning. Iconic photographs are simple in composition and meaning; the essential information carried by the immolation icon is that a terrible sacrifice was made by a Buddhist monk in 1963. The video chosen for the introduction offers a satisfactory equivalent and makes for an effective reference. On the other hand, there is no video close to reproducing the Kent State Shooting icon. In its place, the filmmakers display familiar images of students throwing tear gas bombs back at police forces and National Guardsmen marching across the Kent State campus. As additional clips of the same large event, these work to complete the thematic overview of the Vietnam War.

For those who know little about the war, seeing these clips—specifically the Napalm Girl—can create an effect of familiarity and encourage them to dive into the story to find out more. For those 
who are well-versed in the history of the war, seeing these clips instead of the iconic photographs can awaken curiosity. Finally, for those who know all about the photographs and videos, this is a bold choice inviting interpretation - overall, this is an engaging introduction and the choice of images has great significance regardless of who is watching.

The choices made by Burns and Novick do not only impact the viewing experience but also the life of the iconic photographs. These have been widely recognizable since the 1990s and their symbolic and rhetorical values have been increasingly scrutinized in journalistic and academic essays — so much so that most people are unable to recall the events they once illustrated. It could be argued that their decontextualization has become so extreme that the filmmakers see an opportunity to bring them back to the fore by giving them a new life. They recontextualize them in the documentary and spend time reconstructing their individual stories in a process that could seem outdated nowadays.

Among the many photographs shown and used in this 18-hour documentary, only the four icons are contextualized. For all of them, the viewers are told - or reminded of - the photographers who took them, the circumstances that led to the events they depict, and how they came to be published in newspapers. The filmmakers detail and highlight their process of creation. These four photographs are also the only photographs shown several times and analyzed in dedicated segments.

\section{Episode 2, 1:03:09. Immolation by Fire}

The icons are not presented as autonomous images. To ensure their recontextualization, the filmmakers always begin their segment with a historical reminder. Quang Duc's self-immolation in Saigon is the climax in the story of the persecution of the Buddhist community by authoritarian Catholic president Ngo Dinh Diem. After detailed explanations of the violent repression and of the political ramifications in South Vietnam, the narrator reaches the moment of the immolation and reads:

On June 10, 1963, Malcolm Browne of the Associated Press received an anonymous tip: something important was going to happen the next day at a major intersection in Saigon. He took his camera. To protest the Diem regime's repression, a 73-year-old monk named Quang Duc set himself on fire.

At this point in the episode, the pace slows down. Previous sequences relied both on videos and photographs, exemplifying the dynamic of protest among the Buddhist population. Conversely, the segment that covers the immolation is entirely made of black and white photographs left on the screen for 5 to 15 seconds. This effectively focuses the viewers' attention on the story told while giving them time to fully meditate on the images shown. The sacrifice is detailed through a chronological series of 
photographs, from monks and civilians gathering at the intersection, to an assistant pouring gasoline on Quang Duc, to the iconic photograph of Quang Duc burning, to a photograph of his charred body, ending on a photograph of a funeral procession.

The iconic photograph is revealed in a gradual, suspenseful effect. When the narrator utters the word "fire," flames appear on the screen. The image is a close-up of the flames sweeping off Quang Duc's face on the right-hand side of the icon. After a few seconds, the camera zooms out of the flame to reveal the figure of the monk. Quang Duc's serene features come into the frame and the narration stops. The viewer is left to take in the scene while listening to grungy music. The narrator then goes on to mention the many donations made by even the poorest Buddhists in the community, who were deeply moved by the sacrifice, and the other monks inspired to self-immolate in the following weeks. The narrative vocabulary used is entirely neutral and, even though the photograph is given considerable space, any subsequent event mentioned is presented as a consequence of the immolation, not of its visual embodiment.

The role of the media is by no means lessened, but it is limited to informing the public. Bill Zimmerman, a former antiwar activist, is interviewed and mentions seeing the picture of the immolation on television. Additionally, the front page of an unidentified newspaper featuring a mid-size print of the photograph is shown on the screen as an example of how the press could use it. ${ }^{8}$ The press is never credited with, or accused of, agitating the public. In fact, these mentions seem to be included merely as indications of where the image originated.

\section{Episode 6, 37:06. Execution in Saigon}

The dramatization of the Saigon Execution is similar but relies more heavily on videos. The tension is high at this point in the documentary, as the narrator has been hinting at the Tet Offensive since the fifth episode. This large-scale attack by the North Vietnamese People's Army and the Viet Cong had been carefully planned months in advance and struck the South Vietnamese and American forces with terrible force during the religious ceasefire for Tet.

The summary execution of a Viet Cong prisoner by South Vietnamese Police Chief Nguyen Ngoc Loan has become a mandatory mention in the story of the watershed month of February 1968.

A different version of the photograph is shown here. The picture that was first published, and which won the World Press Photo of the Year in 1963, was in fact taken from a slightly different perspective. In it, the figure of the monk is fully engulfed in dark flame and the resulting image is much bleaker than the version that became iconic. 
Here again, the filmmakers aim for a balanced approach and give the execution only a few minutes of air time out of the total hour of Tet Offensive retelling. As for the immolation, we are presented with a gradual unveiling of the picture, starting with chronological photographs of the prisoner as soldiers brought him to Loan. We then see a clip from the video filmed by an NBC crew; the voice over these images says: "As an AP photographer and an NBC cameraman watched, Loan ordered another officer to shoot the captive. When he hesitated, Loan did the job himself." The video is cut before Loan presses the trigger and the documentary moves to the oral testimony of a South Vietnamese soldier then present. He describes Loan's resolve in very few words, providing the segment with a valuable first-hand account of the scene, and we are then brought back to the video of the execution. This time it is artificially embedded into the frame of a television monitor to reproduce the experience of seeing it on the news - the execution was shown on the news and seen by millions of Americans, which only partially explains why it is so well remembered - iconization was achieved primarily because of reprints in the 1990s national press. But at this point in the documentary, the photograph has not been shown and the media are no more mentioned.

It is only at the end of the long sequence on the Tet Offensive successive battles that the narration moves on to military, political and social consequences. At this point, media coverage is discussed:

Night after night for weeks, American television screens had been filled with images of blood and violence and devastation the public had rarely seen before. But it was one photograph that for many people would come to define the Tet Offensive. (episode 6, 54:07)

The filmmakers carefully touch upon the subject of the strained relationship between the media and Johnson's administration. They do not comment on it or take sides, but merely play tapes of Johnson reprimanding journalists and explain why press coverage appeared biased when it focused on the fighting in Saigon. The antagonism between the media and the administration has become as much a part of history as the battles themselves; and it is this important story that the iconic photograph is made to illustrate. The video shown on television and the incomplete press coverage are blamed more often than the photograph for confusing public opinion; this is shown in Johnson's tape for instance. Yet, by choosing to delay the unveiling of the iconic photograph until this late segment, the filmmakers remind the viewers of the controversy it now embodies - the photograph does not only open a conversation about violence in war, but also acts as a meta-document. Indeed, showing the photograph on the screen is the starting point for a reconstructed debate on media objectivity, violence in the news and the price to pay to reach full political transparency. 


\section{Episode 8, 1:39:37. A Shooting at Kent State}

The chapter on the 1970 university strikes and unrest leading to the shooting at Kent State is significantly detailed. Although the filmmakers are generally supportive of the antiwar movement, this chapter does not amount to a partisan retelling of the year 1970; instead, it demonstrates a desire to educate modern viewers.

Since the end of the war, the antiwar movement, as part of the countercultural movements, has been somewhat romanticized and its prevalence magnified. But as historian George C. Herring notes:

The impact of the antiwar protests remains one of the most controversial issues raised by the war. [...] Antiwar protest did not turn the American people against the war, as some critics have argued. (Herring 173)

Herring adds that inner divisions slowed the movement's momentum for the first few years and that the widespread dislike of hippies - with whom the antiwar movement was widely associatedheightened popular resistance to its ideology. There is no denying that the countercultural movements of the 1960s were tremendous agents of gradual social change and that the antiwar movement occurred on an unprecedented scale. However, even though it had gained remarkable momentum by the late 1960s, the movement continued to face criticism. Despite its large numbers, it either held beliefs that were not on a par with those of the majority of the American population or used methods that the public disapproved of as late as 1970 (Domke 137; Hammond 175).

After the war was lost, iconic photographs came to memorialize the objects and events that needed to be inscribed into social memory to allow for recovery and atonement in a natural effect of crystallization of history into key actors and events (Rouquet, "Shaping the Notion"). The icon from Kent State therefore tends to be read as an embodiment of the political attacks of the antiwar movement and used as evidence that the movement was eventually vindicated. Overall, along with pictures of protesters offering flowers to armed policemen, this iconic photograph has come to symbolize the persuasive strength of the movement inaccurately.

Whether or not this is true to the picture's content is not the point. The symbolism of iconic photographs is strong. But the filmmakers identify a great opportunity to use this familiar image to make a contribution to modern history: the insistence on the strength of the antiwar movement tends to downplay the pervasiveness of American conservatism in the 1970s. Here, the filmmakers wish to remind their viewers of that conservatism. After detailing how the events of Kent State unfolded and 
narrating the confrontation between students and National Guardsmen over other photographs and videos taken on the campus, the iconic photograph is shown on the screen. It is not used in this documentary to declare that the sacrifice of the antiwar movement convinced the public, but to highlight the paradox in its memorialization. The Ohio governor is quoted calling protesters Brown Shirts; the Hard Hats riot and its support by President Nixon is reported in detail because it was a response to students protest; Gallup polls are quoted because they show how critical the general public was of students favoring what they saw as an ideological protest over going to class. As the narrator reminds viewers: " $58 \%$ of the American people thought the killings justified," and that does not include the disproportionate numbers who blamed the students for what happened, those who wrote to their newspaper editors to openly castigate the movement and those who sent hate mail to the families of the victims.

The iconic picture, like the previous icons, is revealed gradually as the climax of an artificial photo essay created by the filmmakers. The author, student photographer John Paul Filo, is briefly mentioned and viewers are given an example of its publication in the Philadelphia Inquirer on May 5, 1970. Since it is a recognizable image, the picture of young Mary Ann Vecchio is used as a visual anchor to the segment on the repression of student protest. The educational value of the segment lies in the reasons why such a shooting could occur and why public reactions would be so reactionary. For a modern viewer who has forgotten about the conservative backlash emerging in those years, the iconic photograph holds the visual evidence of the vehement resistance to antiwar sentiment.

\section{Episode 9, 1:18:30. Attack by Napalm}

The photographer who immortalized Kim Phuc crying in agony is still alive and has had a long and successful career. He is therefore interviewed in this documentary and his testimony is at the center of this segment. The story of the napalm attack is situated in its context: after the Easter Offensive South Vietnamese forces moved on the village of Trang Bang to dislodge North Vietnamese that had previously occupied it. Civilians fled the village. A South Vietnamese fighter confused them for the enemy and dropped napalm on them.

This segment, unlike the others, is a simple celebration of photojournalism. The story it tells is commonplace in the historiography, but it is based on the same gradual unveiling of the icon that we saw previously. Here, photographer Nick Ut describes the attack and narrates his reaction. After taking photographs of the family running on Highway One, he and the BBC London camera crew present at the scene helped Kim Phuc to a hospital. The editing in this segment emphasizes the importance of photography in this story. The segment starts with a distant black and white shot of Trang Bang and plays the sound of camera shutters closing several times. There is something cathartic about the 
way the events are presented on the screen: videos are shown when available and viewers are able to follow Kim Phuc running on the road, crying, receiving water from the crew and soldiers. Some photographs are interspersed in the sequence, but the icon is saved until the end, truly presented as the result of the reporter's work.

Nick Ut explains his process and mentions several times that he was aware that he had a good picture. A picture of himself developing photographs at the A.P. headquarters then appears on the screen, followed by the awaited icon. The image is introduced in two stages, first as a negative and then as a printed photograph; this again helps viewers reflect on the long process involved in producing pictures. The narrator mentions the debate within the A.P. over the sensitive content of the photograph. Horst Faas was adamant that it should be sent on the wire and that resulted in its being published in newspapers around the world - this is narrated over the image of a German newspaper.

There is a definite evolution in the treatment of iconic photographs in this series. The Napalm Girl is the most recent icon and arguably the most significant. In this segment, the narrator does make a careful reference to its potential impact on society: "For many Americans, even many of those who had supported the war, the image seemed to signal that enough was enough." Overall the segment is a testimony to how strongly this picture has become attached to the principle of persuasion; it seems that this photograph cannot be detached from its memorialized symbolism and visual eloquence. It therefore serves two purposes: proving the excellence of photojournalism and reflecting on the state of American society, which, by 1972, was overwhelmingly hoping for an end to the armed conflict.

\section{Visual Eloquence and Persuasion}

Burns and Novick's documentary is not entirely devoid of references to the influence of iconic photographs. In fact, the suggestion of influence we find in the story of the Napalm Girl is not the most direct. The filmmakers themselves make no further mention of the supposed direct influence of icons on public opinion. They do, however, feature interviews of veterans who suggest influence in two of the icons' dedicated segments. At the end of the segment on the Tet Offensive (episode 6, 54:06), James Willbanks, a former army advisor in Vietnam, states:

I think many Americans began to ask themselves “Are we supporting the wrong guy here?" It brings home to the dinner table or breakfast table $[\ldots]$ the brutality of this war and the fact that it looks like it's never going to end. 
The vocabulary used in this oral testimony recalls the part of the historiography that encouraged the development of the influence theory and partly originated in press articles such as this one by James Reston dated from 1975:

Maybe the historians will agree that the reporters and the cameras were decisive in the end. They brought the issue of the war to the people, before the congress or the courts, and forced the withdrawal of American power from Vietnam. (Reston 41)

The same expression was used in a Time photo essay from 1972 entitled "A Gallery of Photos That Brought the War Home." "Bring the war home" was a familiar phrase during the war, just like "winning the hearts and minds"; it was used as a rhetorical tool to convey a variety of different messages. The belief in direct influence is still fairly common today, even though historians of the media and of war photography have worked to rectify it and to explain the nuances of the word. Caroline Brothers notably wrote that the iconic images of the Napalm Girl and the Saigon Execution "articulated and retrospectively pinpointed shifts in the groundswell of attitudes to the war but were unable to bring about these changes themselves" (Brothers 203).

At the end of the segment on the Kent State icon, two veterans who had returned home and seen the picture in the newspapers tell of their emotional reactions to the story. Bill Ehrhart, a former Marine corporal, says:

And here is this very famous photograph, and I just looked at this thing... and I came unglued. [...] Just had a breakdown. Just crying, sobbing uncontrollably. [...] And whenever I finally cried myself out, I got up and I joined the antiwar movement. (Episode 8, 1:44:55)

Former Marine John Musgrave is next heard saying:

I remember when the kids were killed at Kent State, and I thought "My God, we're killing our own children now. We've really gone mad". [... I wasn't in anybody's movement then. I was just drinking. But that was one of the things that told me America needed a wake-up call. (Episode 8, 1:46:01)

The emotion is palpable in these testimonies and they do bring relatability to the documentary and visibility to the ordeals of veterans. The argument here is not to call into question the reliability of these testimonies. Memories can be fragile and historian Jerry Lembcke notes: 
Ground-up views are susceptible, especially after 40 years, to the very myths they are supposed to belie. Memories that are 40 years old are too influenced by movies, novels, newspapers, and television-or those dreaded historians - to count for documentation. (Lembcke n.p.)

There is a possibility that these veterans' memories have been partly modified by what they read in newspapers. They could also be remembering those moments with great accuracy. The reason why these moments are relevant for this study is merely that they were included. In fact, The Vietnam War is an important contribution to the historiography and a testimony to how much the influence theory has altered the memory of media involvement. Even if these particular memories are accurate, a survey carried in May 1970 would have been necessary if one wanted to ascertain the spread of this phenomenon. The filmmakers seem to include them merely to give marginal representation to the idea that some Americans, civilians or veterans, might have felt a connection to what they read and saw in newspapers, which would explain why the theory of influence is still so widespread.

\section{Conclusion: What Do Icons Do to The Documentary?}

Iconic photographs are given a new life here, as Burns and Novick add to their historiography and memorialization. Much thought has been directed toward an understanding of what media images do to social and cultural memory. When dealing with iconic images, Burns and Novick give us a middle ground that discourages a sensationalized reading of press photography and provides an easier way to rehistoricize icons.

The filmmakers no doubt made it a point to direct a documentary that was as balanced and informed as possible. With a focus on the military side of the story, they gave average space to the media. However, iconic photographs have gained such prevalence in social and cultural memory that they now command an inclusion in historical documentaries. But they are not simply mentioned. In fact, all four icons are part of a suspenseful build-up before they are shown on the screen. Gradually revealed through references to other pictures and videos, they are depicted as objects that contribute to and sustain the visual archive of the war. It could be argued that they are treated with reverence, for their ability to unite all the actors of the war in a set of universal memories. At the same time, they allow for a rediscovery of history by playing with expectations and engaging with viewers.

It is not only iconic photographs that the filmmakers make space for in this series, but also iconic people and moments. Walter Cronkite and the 1967 March on the Pentagon are also given good visibility and will resonate with many viewers. This does not mean that Burns and Novick fall into 
the trap of selective historiography. Their documentary is designed as a comprehensive account, but giving proportionately more space to iconic elements is an effective way of injecting rhythm into an otherwise monotonous narrative. This also allows the filmmakers to involve the viewers in the historical retelling by calling upon what they know of their nation's historical and cultural legacy, while at the same time participating in the writing and transmission of this legacy. In short, the inclusion of iconic material into this documentary facilitates a collective historical and cultural experience.

As representations of suspended and crystallized moments, icons provide breaks for contemplation and reflection in this lengthy work; viewers can then observe grim moments of history through an acceptable lens. Icons have indeed been consecrated in cultural memory because their content is sensitive but not gruesome - this separates them from the My Lai massacre pictures, which contain elements of gore and therefore could not be circulated as widely. Here, iconic photographs provide relief to the tired viewer who needs to feel a modern connection to an old piece of history. The fact that icons are chosen as key references to build this connection as early as the introduction sequence shows how deep an impact they have had on collective consciousness.

In the 1990s, iconic photographs were promoted by photojournalists to legitimize their work and showcase their contribution to history and culture. They had to be selected, simplified and deprived of most of their context to become the embodiments of the profession's excellence. It now seems that they have been scrutinized, criticized and praised enough to become bridges between different topics. They can be celebrated both as memorable pictures and presented as historical documents; they carry enough significance to guide and give rhythm to a historical retelling in which there now is space for a celebration of the work of photojournalists outside of their own field.

\section{Works Cited}

“A Gallery of Photos That Brought the War Home.” Time (November 6, 1972): 14-30.

ACHENBACH, Joel. "Did the news media, led by Walter Cronkite, lose the war in Vietnam?". The Washington Post online (May 25, 2018). URL: https://www.washingtonpost.com/national/did-the-news-media-ledby-walter-cronkite-lose-the-war-in-vietnam/2018/05/25/a5b3e098-495e-11e8-827e-190efaf1f1ee_story. html?utm_term=.dde282ddeb3d (page accessed March 3, 2019).

BROTHERS, Caroline. War and Photography: A Cultural History. London and New York: Routledge, 1997. BURNS, Ken and Lynn NOVICK (dir.). The Vietnam War. PBS (2017). 
BURNS, Ken and Lynn NOVICK. "Vietnam's Unhealed Wounds." Op-Ed. The New York Times online (May 29, 2017). URL: https://www.nytimes.com/2017/05/29/opinion/ken-burns-lynn-novick-vietnam-war.html (page accessed March 3, 2019).

DOMKE, David, PERLMUTTER, David and Meg SPRATT. "The Primes of our Times?: An examination of the 'power' of visual images." Journalism 3:2 (2002):131-159.

FOLEY, Michael Stewart. "There is no single lie in war (films): Ken Burns, Lynn Novick and The Vietnam War.” The Sixties 11:1 (April 2018): 93-104.

GOLDBERG, Vicki. The Power of Photography: How Photographs Changed our Lives. 1991. New York: Abbeville Publishing Group, 2003.

HALLIN, Daniel C. The "Uncensored War": The Media and Vietnam. Oxford and New York: Oxford University Press, 1986.

HAMMOND, William H. Reporting Vietnam: Media and Military at War; Kansas: University Press of Kansas, 1998.

HERMAN, Edward S. and Noam CHOMSKY. Manufacturing Consent: The Political Economy of the Mass Media. New York: Pantheon Books, 1988.

HERRING, George C. America's Longest War: The United States and Vietnam 1950-1975. New York: Alfred A. Knopf, (second edition) 1986.

LEMBCKE, Jerry. "Burns and Novick, Masters of False Balancing." Public Books (September 15, 2017). URL: http://www.publicbooks.org/burns-and-novick-masters-of-false-balancing/ (page accessed March 3, 2019).

LEVERING, Robert. "Ken Burns' powerful film on Vietnam ignores the power of the anti-war movement." Open Democracy online (December 7, 2017). URL: https://www.opendemocracy.net/en/transformation/ ken-burns-powerful-film-on-vietnam-ignores-power-of-anti-war-movement/ (page accessed March 3, 2019).

MARIEN, Mary Warner. Photography: A Cultural History. New York: Laurence King Publishing, 2002.

MOYAR, Mark. "What Ken Burns Omits From The Vietnam War.” Providence (Winter 2018): 22-25.

PONIEWOZIK, James. “Review: Ken Burns's 'Vietnam War' Will Break Your Heart and Win Your Mind.” The New York Times online (September 17, 2017). URL: https://www.nytimes.com/2017/09/14/arts/television/ review-ken-burns-the-vietnam-war-pbs.html (page accessed March 3, 2019).

RESTON, James. “The End of the Tunnel.” The New York Times (April 30, 1975): 41.

ROUQUET, Camille. Les icônes du Vietnam et leur pouvoir. Mécanismes de consécration des images photojournalistiques et rhétorique de l'influence des médias depuis la guerre du Vietnam. $\mathrm{PhD}$ manuscript. Paris: Université Sorbonne Paris Cité, 2017. 
—. "Shaping the Notion of Media Influence: The Remediated Images of the Vietnam War." LEAVES 7 (January 2019) online. URL: https://climas.u-bordeaux-montaigne.fr/images/Leaves/leaves07/Remediation_-_Rouquet_article.pdf (page accessed March 3, 2019).

SHEPARD, Alex. "The Insidious Ideology of Ken Burns's The Vietnam War." The New Republic online (September 19, 2017). URL: https://newrepublic.com/article/144864/insidious-ideology-ken-burnss-vietnam-war (page accessed March 3, 2019).

"Slava Veder of Associated Press." The Pulitzer Prizes. URL: https://www.pulitzer.org/winners/slava-veder (page accessed March 3, 2019).

“The Vietnam War: A Film by Ken Burns and Lynn Novick." Public Broadcasting Service. URL: http://www. pbs.org/kenburns/the-vietnam-war/about/press-and-events/ (page accessed March 3, 2019).

Vietnam 10 Years Later: What Have We Learned? Roundtable at Fort Benjamin Harrison, Defense Information School. Indiana: Department of the Army, 1984.

“100 Most Influential Images of All Time.” Time Magazine online. URL: http://100photos.time.com (page accessed March 3, 2019).

Abstract: This is a foray into The Vietnam War, the documentary series directed by Ken Burns and Lynn Novick and released by PBS in September 2017. Through this new historical retelling, the directors aim at reconciling the nation with its painful history. New documents are revealed and old documents are reconsidered. The role of the media during the war, which has been subjected to much historiographical debate, is viewed from a different angle. Iconic photographs used to be deemed influential and have deeply impacted the social memory of the war. They are now reinserted into history to contribute to a new educational approach. This is a new stage in the general historiography of the war in Vietnam.

Résumé : Cet article explore la série documentaire The Vietnam War, de Ken Burns et Lynn Novick, diffusée par PBS en septembre 20I7. Par leur relecture historique nouvelle, les réalisateurs veuillent réconcilier la nation avec une période douloureuse. Ils y révèlent de nouveaux documents et en analysent d'anciens d'une façon nouvelle. Le rôle des médias durant la guerre, qui a provoqué de vifs débats historiographiques, est envisagé sous un angle neuf. Des photographies iconiques ont longtemps été considérées comme ayant eu une influence sur le cours des événements et ayant laissé une trace dans la mémoire collective. Elles sont maintenant réexaminées et retrouvent une place dans l'histoire pour jouer un rôle éducatif. Nous sommes donc à un tournant de l'historiographie de la guerre du Vietnam. 